\title{
Ecotoxicological assessment of flocculant modified soil for lake restoration using an integrated biotic toxicity index
}

\author{
Zhibin Wang, Honggang Zhang, Gang Pan* \\ Research Center for Eco-Environmental Sciences, Chinese Academy of Sciences, Beijing, 100085, China
}

\section{A R T I C L E I N F O}

\section{Article history:}

Received 4 March 2015

Received in revised form

22 July 2015

Accepted 18 August 2015

Available online 21 August 2015

\section{Keywords:}

Chitosan

Cationic starch

Modified soil

Ecotoxicity

Aquatic organisms

\begin{abstract}
A B S T R A C T
Flocculant modified soils/clays are being increasingly studied as geo-engineering materials for lake restoration and harmful algal bloom control. However, the potential impacts of adding these materials in aquatic ecological systems remain unclear. This study investigated the potential effects of chitosan, cationic starch, chitosan modified soils (MS-C) and cationic starch modified soils (MS-S) on the aquatic organisms by using a bioassay battery. The toxicity potential of these four flocculants was quantitatively assessed using an integrated biotic toxicity index (BTI). The test system includes four aquatic species, namely Chlorella vulgaris, Daphnia magna, Cyprinus carpio and Limnodrilus hoffmeisteri, which represent four trophic levels in the freshwater ecosystem. Results showed that median effect concentrations $\left(E_{50}\right)$ of the MS-C and MS-S were 31-124 times higher than chitosan and cationic starch, respectively. D. magna was the most sensitive species to the four flocculants. Histological examination of $C$. carpio showed that significant pathological changes were found in gills. Different from chitosan and cationic starch, MS-C and MS-S significantly alleviated the acute toxicities of chitosan and cationic starch. The toxicity order of the four flocculants based on BTI were cationic starch $>$ chitosan $>$ MS-S $>$ MS-C. The results suggested that BTI can be used as a quantitative and comparable indicator to assess biotic toxicity for aquatic geo-engineering materials. Chitosan or cationic starch modified soil/clay materials can be used at their optimal dosage without causing substantial adverse effects to the bioassay battery in aquatic ecosystem.
\end{abstract}

(C) 2015 Elsevier Ltd. All rights reserved.

\section{Introduction}

Over the past several decades, harmful algae blooms (HABs) have frequently occurred worldwide, causing serious ecological and economic impacts to aquatic ecosystems and human health (Akyuz et al., 2014; Paerl and Huisman, 2008). Several chemical (Burson et al., 2014; Fan et al., 2013), mechanical (Li et al., 2014) and biological techniques (Kim et al., 2007; Nan et al., 2008) have been developed to reduce these impacts. Recently, lake geo-engineering techniques are discussed in solving this problem. The term "geoengineering", defined as achieving a desired chemical or ecological response by adding materials such as a modified clay or metal compound to a lake (Mackay et al., 2014). The range of materials used is growing and includes engineered materials, commercially available salts, flocculants, clay/soils and industrial by-products (Spears et al., 2014).

\footnotetext{
* Corresponding author.

E-mail address: gpan@rcees.ac.cn (G. Pan).
}

Although these materials may be useful in controlling nutrient level, there is a need to evaluate the impacts of adding exogenous materials to the aquatic ecosystem. Reports indicate that some chemical materials exhibit toxicity to aquatic biota. The lanthanummodified clay (Phoslock ${ }^{\circledR}$ ) is promising in holding phosphorus in the sediment (Meis et al., 2013), but the population growth rates of daphnia are $6 \%$ and $20 \%$ lower than the control at 100 and $1000 \mu \mathrm{g}$ La/L, respectively (Lürling and Tolman, 2010). Clearwater et al. (2014) demonstrate that fingernail clam survival is adversely affected by high dosage ( $344 \mathrm{~g}$ alum $/ \mathrm{m}^{2}$ ) of alum application and some aluminum accumulation occurred in the crayfish and mussels (Clearwater et al., 2014). The aqueous Al can increase the risk of infection in the crayfish by impairing the ability of haemocytes to recognise and/or remove bacteria from the circulation (Ward et al., 2006). Recent studies indicate that toxic $\mathrm{Al}^{3+}$ could be released after alum application at low $\mathrm{pH}(<6.0)$, and sediment-capping with alum could inhibit microbial nitrification and denitrification under aerobic conditions (Gibbs and Oezkundakci, 2011).

Recently, natural flocculant materials, such as chitosan and 
cationic starch, were developed as environmental friendly materials to control harmful algal blooms because of their high flocculation efficiency (Anthony and Sims, 2013; Hansel et al., 2014; Letelier-Gordo et al., 2014; Xu et al., 2013). To improve the HABs removal using clays, chitosan is used to modify the local soils and applied to small natural waters to control both cyanobacteria blooms and sediment nutrient release, leading to recovery in submerged macrophytes (Li and Pan, 2015, 2013; Pan et al., 2012). Anthony and Sims (2013) find that cationic starch can effectively flocculate algae cells and remove total phosphorus in wastewater with an upward trend of TP removal with increasing dosage. Cationic starches serve as substrates in anaerobic digestion or fermentation processes using the harvested biomass as feedstock and such biomass can be safely used as animal feed or fertilizer (Anthony and Sims, 2013). Cationic starch modified soil has been reported by Shi et al. (2016) as the effective algae flocculant with the loading of $0.11 \mathrm{~g} / \mathrm{L}$ for a removal efficiency of $86 \%$. Although chitosan and cationic starch have been used in wastewater treatment and the removal of HABs in aquatic system, there are little studies on their toxicity effects on aquatic ecological system when they are applied in field (Li and Pan, 2013). It is necessary to evaluate the biotic toxicity of chitosan and cationic starch by using appropriate test methods.

Conventional methods of assessing toxicity effect of flocculants are to expose a single species to the flocculent solutions over a range of concentrations for a certain period of time, but the results may be not sufficient because a single organism cannot represent an aquatic ecosystem. Therefore, the application of a battery of bioassay tests with organisms belonging to different trophic levels is recommended and developed (Hartwell, 1997; Nowell et al., 2014; Wei et al., 2011). Antunes et al. (2007) use a battery of bioassays (algae, crustaceans and dipterans) to screen the acute toxicity of water column and sediment from an abandoned uranium mine, and find that Daphnia longispina is the most sensitive organisms (Antunes et al., 2007). In order to evaluate the effects of human activities on the biosafety of water quality, Wei et al. (2008) develop an evaluation method using algae, daphnia and larval medaka (Wei et al., 2008). Tigini et al. (2011) study the toxicity of simulated textile and tannery wastewaters by using a battery of seven organism bioassays and find that the algae Pseudokirchneriella subcapitata is the most sensitive organism (Tigini et al., 2011). While bioassay battery tests can provide more information than single species test to assess the toxicity of chemicals, it is still hard to quantitatively evaluate the biotic toxicity of biodegradable and/ or non-degradable chemicals to the aquatic ecosystem and to the food chain.

Several integrated assessment toxicity models have been developed to evaluate the biotic toxicity in the field of pesticide and wastewater treatment. Potential ecotoxic effects probe (PEEP) index was developed to assess and compare the toxic potential of industrial effluents (Costan et al., 1993). Nowell et al. (2014) used Pesticide Toxic Index (PTI) to evaluate relationships between pesticide exposure and biological condition (Nowell et al., 2014). However, the information about the biotic toxicity of flocculants to the aquatic organisms is very limited. There is an urgent need to develop an integrated biotic toxicity index to assess toxicological effects of chemicals on the aquatic organisms.

This paper aims to investigate the biotic toxicity of chitosan, cationic starch, chitosan modified soil (MS-C) and cationic starch modified soil (MS-S) to the aquatic organisms and elucidate the mechanism of the toxic effect by means of a battery of four bioassays that belong to different trophic levels. An integrated biotic toxicity index (BTI) was developed to make a comprehensive and comparable assessment on the biotic toxicity of the added flocculants on the aquatic organisms.

\section{Materials and methods}

\subsection{Soil and flocculants}

The soils and chitosan used in this study were described in a previous study (Li and Pan, 2013). Cationic starch was obtained from Minsheng Environmental Technology Co. Ltd, Dalian, China. The cationic starch was dissolved by adding $250 \mathrm{mg}$ cationic starch to $100 \mathrm{~mL}$ deionized water. The molecular weights (MW) of chitosan and cationic starch are $5 \times 10^{5} \mathrm{~g} / \mathrm{mol}$ and $1 \times 10^{8} \mathrm{~g} / \mathrm{mol}$, respectively. The chitosan modified soils (MS-C) and cationic starch modified soils (MS-S) were obtained by adding $100 \mathrm{~mL}$ chitosan solution $(5 \mathrm{mg} / \mathrm{mL})$ or $100 \mathrm{~mL}$ cationic starch solution $(2.5 \mathrm{mg} / \mathrm{mL})$ to $100 \mathrm{~mL}$ soil suspension $(50 \mathrm{mg} / \mathrm{mL}$ ), respectively. The mixture was well stirred and then ready for use in the toxicity experiment.

\subsection{Test solution}

BG11 medium was used for algae growth inhibition test only. The solution was adjust to $\mathrm{pH} 8.2$ by adding either $0.5 \mathrm{~mol} / \mathrm{L} \mathrm{NaOH}$ or $0.5 \mathrm{~mol} / \mathrm{L} \mathrm{HCl}$ solutions after autoclaving (Li and Pan, 2013). The artificial water with a $\mathrm{pH}$ of 7.8 , a total hardness of $250 \mathrm{mg} \mathrm{CaCO}_{3} / \mathrm{L}$ was used for the other tests. The dissolved oxygen values were maintained at $8.0 \mathrm{mg} / \mathrm{L}$.

\subsection{Aquatic organisms}

\subsubsection{Chlorella vulgaris}

The green algae $C$. vulgaris (FACHB-1227) were obtained from the FACHB, Institute of Hydrobiology, Chinese Academy of Sciences, and cultured in BG11 medium, at $25 \pm 1^{\circ} \mathrm{C}$ and with a $12 \mathrm{~L}: 12 \mathrm{D} \mathrm{h}$ photoperiod in an illuminating incubator. At the start of new cultures, algae were harvested during the exponential growth phase and inoculated in fresh medium.

\subsubsection{Daphnia magna and Limnodrilus hoffmeisteri}

The D. magna and L. hoffmeisteri were isolated from Lake Taihu, China and were maintained in artificial water at $25 \pm 1{ }^{\circ} \mathrm{C}$, on a $16 \mathrm{~h}$ light and $8 \mathrm{~h}$ darkness regimen. The average weight of the L. hoffmeisteri was $40 \pm 10 \mathrm{mg}$, and the average body length was $10 \pm 2 \mathrm{~mm}$. D. magna were fed with Scenedesmus obliquus $\left(10^{6}\right.$ cells/ $\mathrm{mL}$ ) and $L$. hoffmeisteri were fed with approximately $100 \mathrm{mg}$ powder fish food every day.

\subsubsection{Cyprinus carpio}

C. carpio, were obtained from a fish farm and acclimated for a month to lab conditions in $100 \mathrm{~L}$ tank filled with artificial water prior to the tests. The average mass/size of $C$. carpio used in the test was $0.5 \pm 0.1 \mathrm{~g} / 3.0 \pm 0.2 \mathrm{~cm}$. The fish were fed with commercial carp food at a rate of $1.5 \%$ of body weight. The tank water was changed weekly. Ammonia, nitrate and nitrite levels were kept below toxic concentrations ( $<0.1 \mathrm{mg} / \mathrm{L}$ ) (Eyckmans et al., 2012).

\subsection{Experiment design}

\subsubsection{Soil leachate and toxicity tests}

Soil materials may potentially release heavy metals into water phase under a variety of conditions. The toxicity characteristic leaching procedure (TCLP) was carried out to determine the mobility of metal elements in soil (USEPA, 1992). The metal elements leached from the soil by three different extraction fluids were analyzed using Inductively Coupled Plasma Emission Spectrometry (ICP-OES, Optima 8300, PerkinElmer, USA). As a complementary test, the effects of soil on four species were determined. Following a static design, the organisms were exposed to five 
concentrations soil $(62.5,125,250,500$ and $1000 \mathrm{mg} / \mathrm{L})$ in BG11 medium or artificial water.

\subsubsection{C. vulgaris growth inhibition test}

The tests were conducted using a $72 \mathrm{~h}$ growth inhibition bioassay. The algae were exposed to 9 dilutions of four flocculant materials. Each treatment had three replicates and was kept in $125 \mathrm{~mL}$ erlenmeyer flask which contained $50 \mathrm{~mL}$ test solution. The initial algae cell density of each treatment was $1 \times 10^{4}$ cells $/ \mathrm{mL}$. The cell density was determined using a Neubauer hemocytometer. The flasks were incubated under cool white fluorescent light of $2000 \mathrm{~lx}$ on a $12 \mathrm{~h}$ light and $12 \mathrm{~h}$ darkness regimen. The $C$. vulgaris suspension in each flask was thoroughly mixed by shaken every $8 \mathrm{~h}$ to prevent cell aggregating. The yield in each individual treatment was calculated as the difference between the cell densities at the end and at the beginning of the test. The inhibition in yield $\left(I_{y}\right)$ was expressed as (Costa et al., 2014):

$I_{y}=100\left(Y_{C}-Y_{T}\right) / Y_{C}$

where $Y_{C}$ and $Y_{T}$ represent the yield for the controls and each replicated treatment, respectively.

\subsubsection{D. magna immobilization test}

Acute toxicity to D. magna was examined with the $48 \mathrm{~h}$ Daphnia magna immobilization test. The acute immobilization tests were conducted in accordance with the USEPA guidelines. Neonates aged less than $24 \mathrm{~h}$ and born within the 3rd to 5th culture broods were used in the test. For each treatment, 10 offsprings were used by $100 \mathrm{~mL}$ flask which contained $50 \mathrm{~mL}$ solution, test in triplicate. The details of concentration setting were provided in (Table S1 in supplementary information). Immobilized organisms were counted after a $48 \mathrm{~h}$ exposure period and the daphnias were not fed during the test.

\subsubsection{L. hoffmeisteri acute toxicity test}

L. hoffmeisteri were exposed to $50 \mathrm{~mL}$ test solutions in $10 \mathrm{~cm}$ Petri dishes for $96 \mathrm{~h}$. The test solution was renewed every $24 \mathrm{~h}$. Each dish contained 5 worms, tested in triplicate. Immobilized organisms were counted after a $96 \mathrm{~h}$ exposure period and the worms were not fed during the test. The details of concentration setting are provided in (Table S1).

\subsubsection{C. carpio acute toxicity test}

The acute toxicity of the four flocculants to C. carpio was evaluated in $96 \mathrm{~h}$ static tests where fish were placed in $1.5 \mathrm{~L}$ of exposure solution in 2 L glass beakers. The test protocol followed ChemicalsFish acute toxicity test (GBT/27861-2011). There were six treatment concentrations with three replicates (Table S1). Each beaker contained 5 fish. Survival was assessed daily and dead organisms removed when found. Survival and changes in gill histology at $96 \mathrm{~h}$ were the primary endpoints.

\subsubsection{Histopathology}

The morphological changes of D. magna, L. hoffmeisteri and C. carpio were observed using a dissecting microscope and imaging software (Image Analysis Syste 13.0). The algae were observed by Axio Scope A1 microscope (Zeiss, Germany) at $400 \times$ magnification.

In the fish acute toxicity test, the live fish were anaesthetized with MS-222, fixed in Bouin's fluid for $24 \mathrm{~h}$, and then processed for histology where $6 \mu \mathrm{m}$ sections per fish per slide were stained with hematoxylin/eosin (H\&E). Gill, liver, kidney, gut, skin and heart histopathology were evaluated using an Axio Scope A1 microscope (Zeiss, Germany) at $400 \times$ magnification.

\subsubsection{Biotic toxicity index (BTI)}

In order to comprehensively and quantitatively assess the toxicological effect on the aquatic organisms after adding the geoengineering materials, a biotic toxicity index (BTI) was established by means of a battery of four bioassays, using organisms that belong to different trophic levels. The BTI was determined according to the equation:

$B T I=X_{A}^{N} \sum_{i=1}^{n}\left(\frac{1}{E C_{50 i}}\right)$

where $X_{A}$ is the practical dosage of material $\mathrm{A}(\mathrm{mg} / \mathrm{L}) . n$ is the number of species in the bioassay battery. $E C_{50 i}$ is the median effect concentrations of the material for the separate species $(\mathrm{mg} / \mathrm{L}) . X_{A}$ and $E C_{50 i}$ are expressed in the same units. The value of $N$ is calculated according to the following three scenarios:

Scenario 1: when the material $\mathrm{A}$ is biodegradable, then $N=1$; Scenario 2: when the material A is non-biodegradable, and the selected test organisms do not have a food chain relationship, then $N=\sum_{i=1}^{n}\left(B C F_{i}\right) / n$, and $B C F_{i}=\frac{C_{S i}}{C_{w}}$, where $B C F$ is bioconcentration factor (McGeer. et al., 2003), $C_{s i}$ is the material concentration in each kind of test organism at steady state ( $\mu \mathrm{g} \mathrm{g}^{-1}$ dry weight), and $C_{w}$ is the material concentration in water $\left(\mathrm{mg} \mathrm{mL}^{-1}\right)$. If $X_{A}=0 \mathrm{mg} / \mathrm{L}$, then $B T I=0$;

Scenario 3: when the material is non-biodegradable, and the test organisms in the bioassay battery are from the same aquatic ecosystem, then $N=B M F=\left(\frac{F_{n} / F}{T L_{n} / T L_{1}}\right)$, where $B M F$ is the biomagnification factor (Hoekstra et al., 2003). $F_{n}$ and $F_{1}$ are material concentrations of the highest and lowest trophic level species, respectively. $T_{L n}$ and $T_{L i}$ is the trophic level of the highest and trophic level species which can be determined by stable isotope ratios of $\delta^{15} \mathrm{~N}$ and $\delta^{13} \mathrm{C}$. If $X_{A}=0 \mathrm{mg} / \mathrm{L}$, then $B T I=0$.

A higher BTI implies that the material has higher risk to the aquatic organisms or aquatic food chain.

\subsection{Data analysis}

$\mathrm{EC}_{50}$ and general statistical analysis of the data are estimated using PASW statistics 18.0 (SPSS software, IBM, http://www-01. ibm.com/software/analytics/spss/). A significance level of 0.05 is used in all statistical analyses.

\section{Results}

\subsection{Toxicity of metals in the soil}

The metal concentrations leached from the soil at $\mathrm{pH} 2.88$ were higher than those at $\mathrm{pH} 4.93$ and $\mathrm{pH} 7.85$. Acidic condition was used to test the maximum potential of heavy metal risk from the soil. Table 1 showed that the metal concentration leached under simulated environmental conditions from the tested soil materials did not exceed the acute $48 \mathrm{~h} \mathrm{EC} 50$ values to $D$. magna (Biesinge. and Christen., 1972).

\subsection{Toxic effects of flocculant materials}

Table 2 indicated that the chitosan appeared to be less acutely toxic than cationic starch, with the $E C_{50}$ for the four organisms being around two times higher than the cationic starch. $E C_{50}$ of the MS-C and MS-S were 31-124 times higher than chitosan and cationic starch. D. magna was the most sensitive species to the four 
Table 1

The concentration of metal elements leached from the soil by three different extraction fluids $(\mathrm{mg} / \mathrm{L})$.

\begin{tabular}{llllr}
\hline Elements $^{\mathrm{a}}$ & \multicolumn{2}{l}{ Concentration of metal elements $^{2}$} & D. magna 48-h $\mathrm{EC}_{50}$ \\
\cline { 2 - 4 } & A leachate $^{\mathrm{b}}$ & B leachate $^{\mathrm{c}}$ & C leachate $^{\mathrm{d}}$ & \\
\hline Aluminum & - & 0.06 & 1.27 & 3.90 \\
Arsenic & 0.10 & 0.08 & 0.08 & 7.40 \\
Barium & - & 0.31 & 0.55 & 14.50 \\
Copper & - & 0.02 & 0.04 & 0.06 \\
Iron & - & 0.07 & 0.29 & 9.60 \\
Magnesium & 2.30 & 4.99 & 8.11 & 140.00 \\
Manganese & 0.14 & 1.57 & 3.35 & 9.80 \\
Plumbum & - & 0.04 & 0.36 & 0.45 \\
Stannum & 0.20 & 0.19 & 0.19 & 55.00 \\
Zinc & - & 0.18 & 0.21 & 0.28 \\
\hline
\end{tabular}

a The following elements were below the detection limit $(<0.01 \mathrm{mg} / \mathrm{L})$ : $\mathrm{Ag}, \mathrm{Be}, \mathrm{Bi}$, $\mathrm{Cd}, \mathrm{Ce}, \mathrm{Co}, \mathrm{Cr}, \mathrm{Se}, \mathrm{Sb}, \mathrm{Sn}, \mathrm{U}$.

b Deionized water, $\mathrm{pH}=7.85$.

c Acetic acid solution, $\mathrm{pH}=4.93$.

d Acetic acid solution, $\mathrm{pH}=2.88$.

flocculants. The order of sensitivity (from highest to lowest based on $E C_{50}$ values) of the four species assessed to the four flocculants was D. magna $>C$. vulgaris $>C$. carpio $>$ L. hoffmeisteri. $E C_{50}$ was not obtained for the soil because only $1.5 \%$ growth inhibition of algae and no immobilization or mortality of daphnia, tubificidae and fish were found at the highest soil concentration $(1000 \mathrm{mg} / \mathrm{L})$ tested. The soil did not show the acute toxicity to the four aquatic organisms.

\subsection{Morphology and histopathology}

The micrographs of the four species exposed to different concentrations of flocculant materials were used to provide an intuitive interpretation of the interaction between the flocculants and biological surfaces. Algal flocs micrographs showed that the four kinds of flocculants could wrap and hold $C$. vulgaris cells and aggregated them into large and complex flocs. Although the $C$. vulgaris cells were thoroughly mixed by shaken to prevent cell clumping, most of the algae cells sink to the bottom compared to the control (Fig. 1 a-2 to a-5). Lots of flocs adhered to the surface of $L$. hoffmeisteri, $D$. magna and the gill tissue of $C$. carpio (Fig. 1 b-2 to b-5, c-2 to c-5 and d-2 to d-5).

Gill, liver, kidney, heart, gut and muscle histopathology were monitored in common carp exposed for $96 \mathrm{~h}$ to the four flocculant materials. Fish acute toxicity tests indicated the histopathological changes were only happened in gill tissue. Gill tissues of fish sampled from the control (Fig. 2a) and the soil control (Fig. 3a) were normal with blood spaces of the lamellae obvious and uniform in size. The gill of fish showed a significant increase in the number of red blood cells compared to the control when they were exposed to $91.9 \mathrm{mg} / \mathrm{L}$ MS-C (chitosan content $8.4 \mathrm{mg} / \mathrm{L}$ ) or $2.0 \mathrm{mg} / \mathrm{L}$ chitosan for $96 \mathrm{~h}$ (Fig. 2c and e). Exposure to $70.0 \mathrm{mg} / \mathrm{L} \mathrm{MS}-\mathrm{S}$ (cationic starch content $3.3 \mathrm{mg} / \mathrm{L}$ ) or $0.8 \mathrm{mg} / \mathrm{L}$ cationic starch for $96 \mathrm{~h}$ also caused a significant increase in the number of gill cells. More seriously, large areas of adjacent lamellas were fused when they were exposed to higher concentrations of modified soil, chitosan and cationic starch (Figs. 2d, f and 3d, f).

The bottoms of the lamellae engorged with red blood cells and significantly increased gill lamellar thickness for the carp exposured to $2.0 \mathrm{mg} / \mathrm{L}$ chitosan (Fig. 2e) and $0.8 \mathrm{mg} / \mathrm{L}$ cationic starch (Fig. 3e), however, the similar pathological symptoms were not found in the fish exposure to $31.8 \mathrm{mg} / \mathrm{L}$ MS-C (chitosan content $2.9 \mathrm{mg} / \mathrm{L}$, Fig. 2b) and $21.6 \mathrm{mg} / \mathrm{L}$ MS-S (cationic starch content $1.0 \mathrm{mg} / \mathrm{L}$, Fig. 3b). The height of the lamellae decreased while the gill lamellas were thickened. (Figs. 2c, e and 3c, e).

\subsection{Biotic toxicity index (BTI)}

Chitosan and cationic starch are easily biodegradable which can hardly accumulate and transfer through food chain (Bolto and Gregory, 2007). In this scenario, parameter $N=1$. Based on the $E C_{50}$ of the flocculants to the bioassay battery (Table 2), the functional relation between $B T I$ and dosage $\left(X_{A}\right)$ of the flocculants was calculated by using formula (2), as shown in Fig. 4. The order of biotic toxicity of the four flocculants to the bioassay battery was cationic starch $>$ chitosan $>$ MS-S $>$ MS-C. The BTI of cationic starch and chitosan was found to increase as the dosage of the flocculants increased. However, the BTI for MS-C and MS-S remained very low which did not have significant change as the dosage increased (Fig. 4).

Based on the practical dosage $\left(X_{A}\right)$ of flocculants in the published literature, we calculated the BTI of Modified soil (MS) and corresponding modifiers, respectively. Table 3 showed that the BTI of chitosan or cationic starch was higher than modified soil which contained the same amount of modifier. Soil could reduce the biotic toxicity of chitosan and cationic starch.

\section{Discussion}

\subsection{Toxic effects of chitosan and cationic starch on aquatic organisms}

Natural flocculant materials are widely studied as geoengineering materials for controlling harmful algal blooms or nutrient levels (Li and Pan, 2013; Wang et al., 2013). Among these flocculants materials such as chitosan and cationic starch are the most promising ones for application due to abundant source, easy availability and biodegradation with less secondary pollution (Hansel et al., 2014; Letelier-Gordo et al., 2014). However, cationic polymers are often toxic to the aquatic organisms (Lee et al., 2014) and direct application of these materials in aquatic environment may pose adverse effects (Bullock et al., 2000; Rizzo et al., 2008).

Cationic flocculants may be toxic to zooplankton and fish because the surfaces of aquatic organisms often carry with net negative charge (Lee et al., 2014). Dissolved chitosan is cationic polymer with high charge density (Rinaudo, 2006). Hence, the chitosan and cationic starch can readily bind to the surface of aquatic organisms. This ultimately can result in toxicity to the aquatic organism due to the reduction of oxygen transfer through

Table 2

$\mathrm{EC}_{50}$ for flocculant materials to the four species.

\begin{tabular}{|c|c|c|c|c|c|}
\hline \multirow[t]{2}{*}{ Test endpoint } & \multicolumn{5}{|c|}{$\mathrm{EC}_{50} / \mathrm{LC}_{50}(95 \%$ confidence interval limits) $(\mathrm{mg} / \mathrm{L})$} \\
\hline & Chitosan & MS-C & Cationic starch & MS-S & Soil \\
\hline 72-h algae yield inhibition & $3.5(2.3-4.5)$ & $110.2(99.9-122.1)$ & $1.8(1.2-2.5)$ & $113.2(94.8-137.3)$ & $>500$ \\
\hline 48-h daphnia immobilization & $2.2(1.6-2.9)$ & $102.0(84.0-126.9)$ & $0.9(0.6-1.4)$ & $90.2(72.4-114.4)$ & $>500$ \\
\hline 96-h tubificidae immobilization & $6.9(5.4-8.1)$ & $323.2(248.7-443.7)$ & $3.7(2.9-4.6)$ & $248.7(192.9-330.3)$ & $>1000$ \\
\hline 96-h fish mortality & $3.0(2.3-3.6)$ & $165.7(125.0-232.0)$ & $1.4(0.8-2.1)$ & $173.1(124.6-268.1)$ & $>1000$ \\
\hline
\end{tabular}




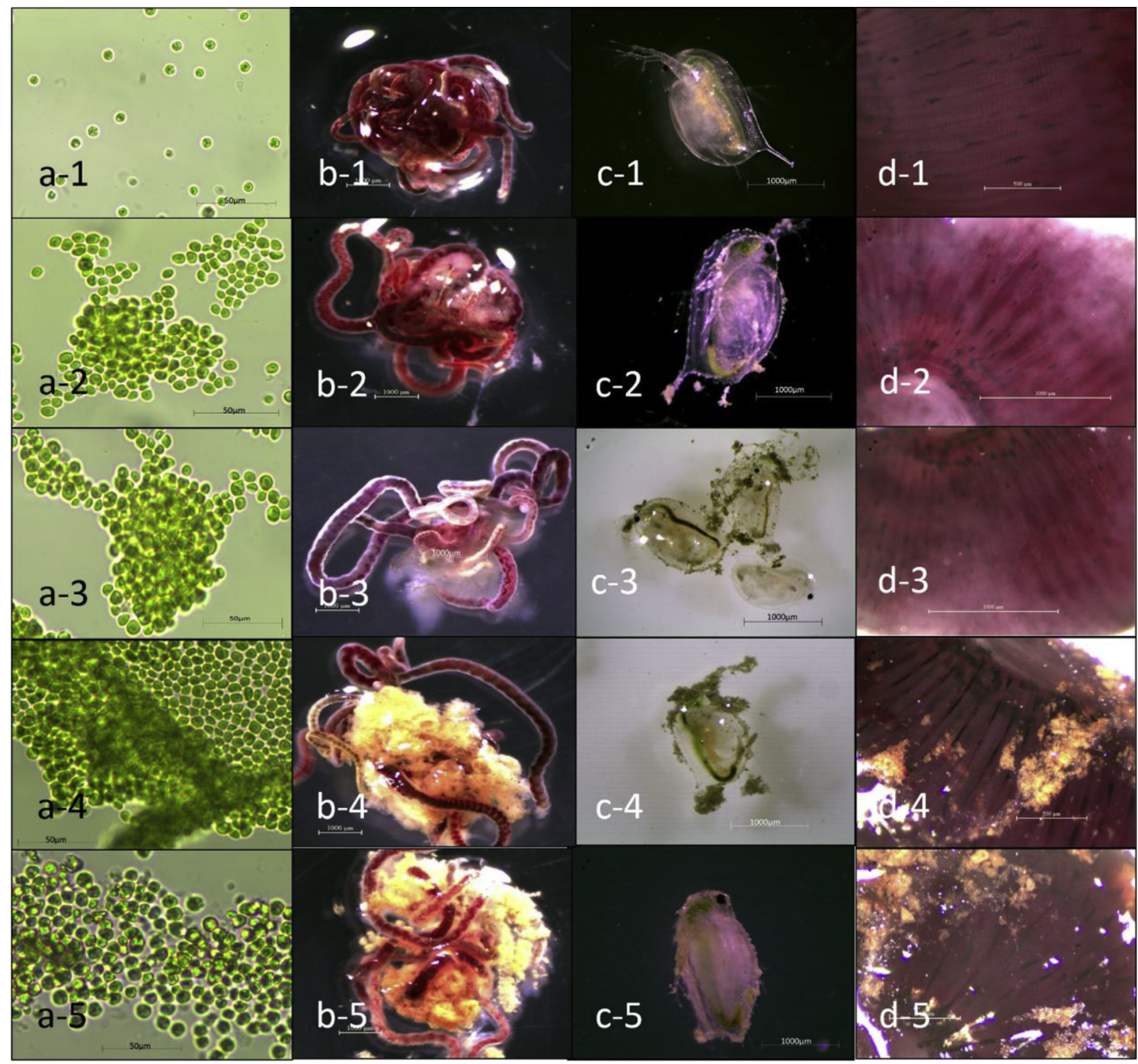

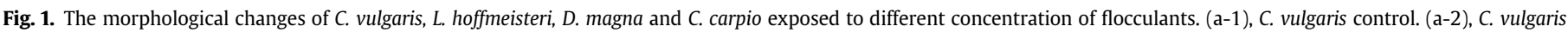

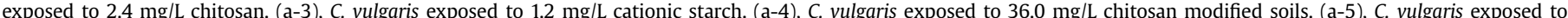

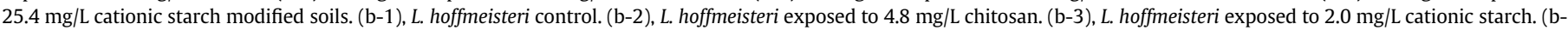

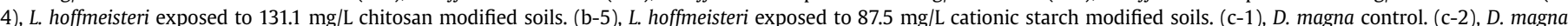

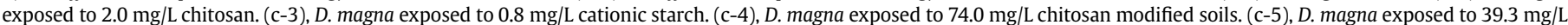

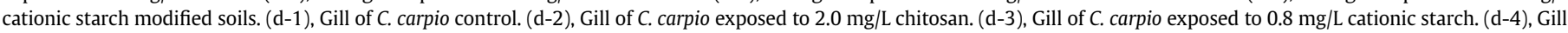
of $C$. carpio exposed to $91.9 \mathrm{mg} / \mathrm{L}$ chitosan modified soils. (d-5), Gill of $C$. carpio exposed to $70.0 \mathrm{mg} / \mathrm{L}$ cationic starch modified soils.

damaged cell surfaces or by effects on the ionic balance.

C. vulgaris cells were agglomerated and sedimented to the bottom at different concentrations of chitosan and cationic starch. Compared to the control, the chitosan and cationic starch do not exhibit a detrimental impact on C. vulgaris cell integrity in $72 \mathrm{~h}$ (Fig. 1 a-1 to a-3). However, C. vulgaris growth inhibition occurred (Table 2). Costa et al. (2014) found that cationic polymers could cause physiological damage to the green microalgae due to the especially strong affinity of the flocculants to the algal cellular surface and further inhibit the proliferation of the cells (Costa et al., 2014). We found lots of white flocs adhere to the surface of D. magna (Fig. 1b) and L. hoffmeisteri, even some cladoceras were stuck together by the cationic starch (Fig. 1c-2). The toxicity effects of the chitosan and cationic starch to the zooplankton may result from mechanical impairment, including locomotion inhibition and disturbance of predation mechanisms (Costa et al., 2014).

Fig. 1d indicated that the flocs of chitosan and cationic starch could adhere to the surface of the gill of the carp and cause thickening and shortening of common carp gill filaments leading to destruction of the filament structure. Large areas of adjacent lamellae are fused when the carp exposure to high concentrations of chitosan and cationic starch (Figs. $2 \mathrm{f}$ and 3 f), which is similar to that observed previously with cationic polymer exposure in lake trout fry (Liber et al., 2005). Since the chitosan and cationic starch with long-chain structure are difficult to pass through the cell membranes (Goodrich et al., 1991), the most likely mechanism of pathological changes of gill tissue is flocculants adsorption onto the organ surfaces. Hence the microenvironment surrounding the gill cells will be altered and transport mechanisms between the cells and the water are disrupted, with further impacts on respiratory and ion regulation processes (Rowland et al., 2000).

\subsection{Toxic effects of chitosan and cationic starch modified soil}

The biotic toxicity of MS-C and MS-S to the bioassay battery was much less than chitosan and cationic starch (Table 2). The adding of 


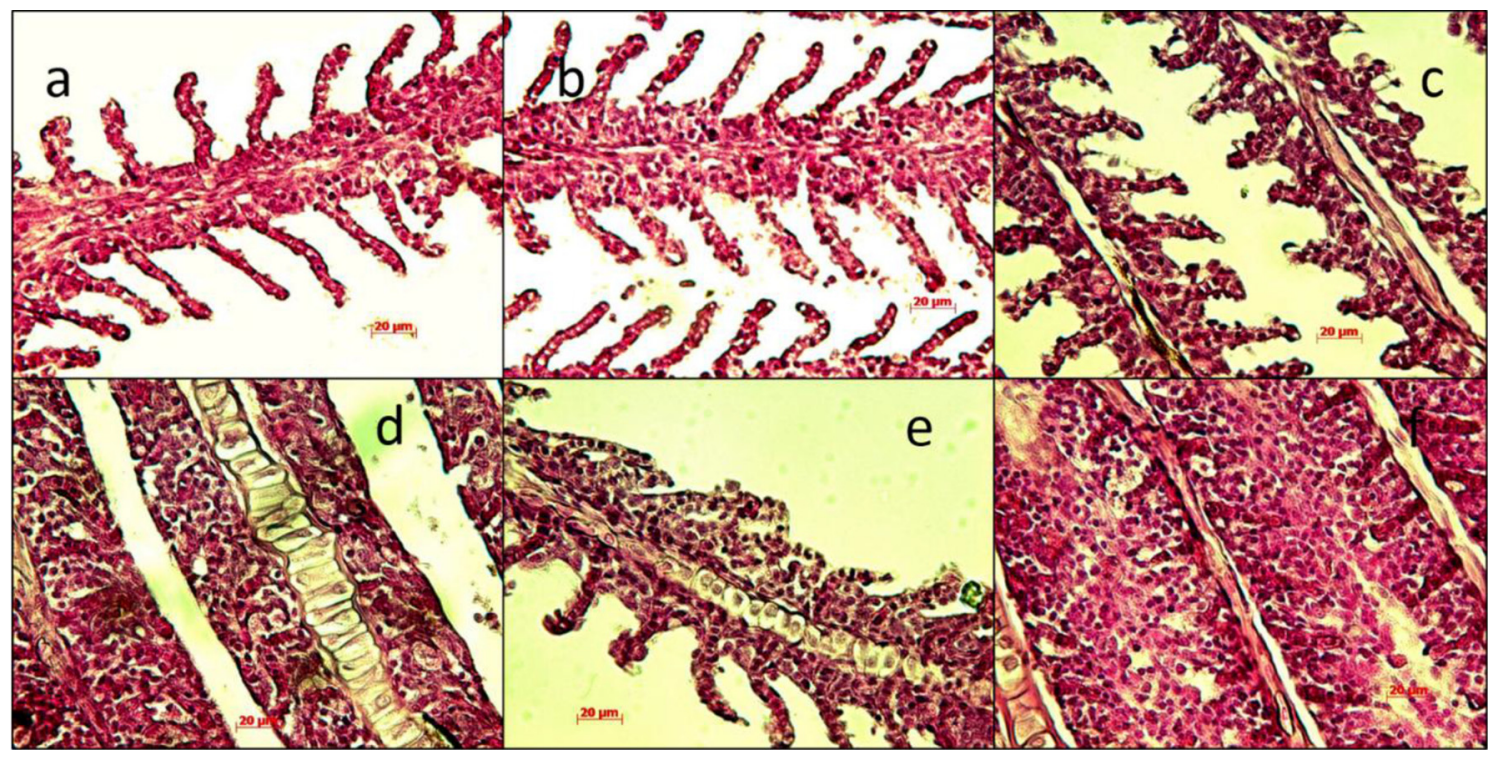

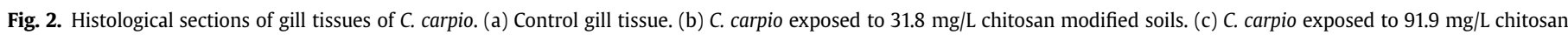
modified soils. (d) C. carpio exposed to $265.5 \mathrm{mg} / \mathrm{L}$ chitosan modified soils. (e) C. carpio exposed to $2.0 \mathrm{mg} / \mathrm{L}$ chitosan. (f) C. carpio exposed to $8.0 \mathrm{mg} / \mathrm{L}$ chitosan.

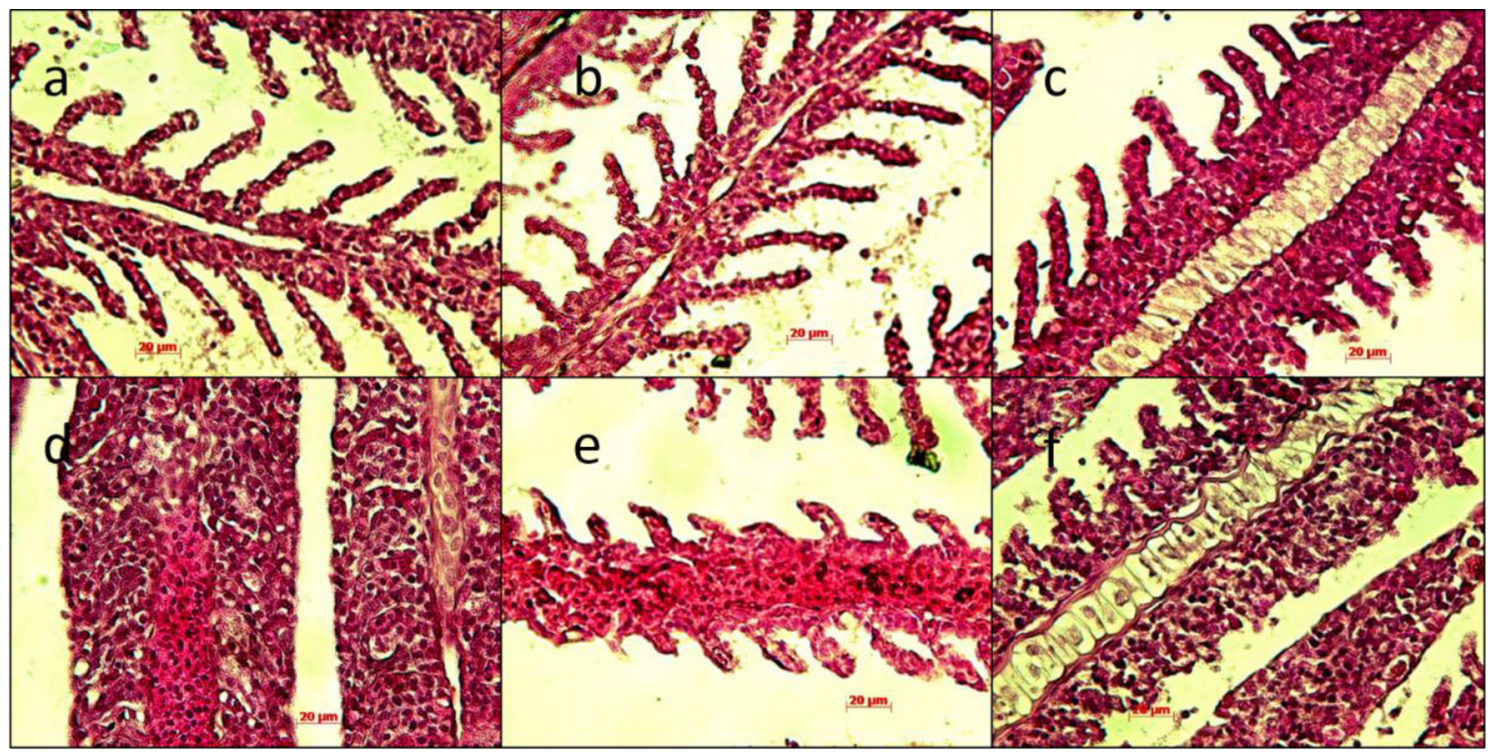

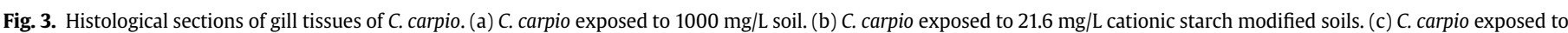

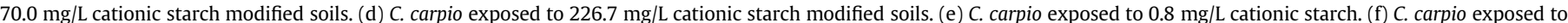
$3.2 \mathrm{mg} / \mathrm{L}$ cationic starch.

soil could reduce toxicities of chitosan and cationic starch by one to two orders of magnitude. Some reports indicated that clays could effectively reduce the acute toxicities of cationic polymers to aquatic organisms (de Rosemond and Liber, 2004). Goodrich et al. (1991) also found that the biotic toxicity of cationic polymer was reduced 33- to 75-fold at higher humic acid concentrations (Goodrich et al., 1991). The adsorption and neutralization of the positive charge of cationic polymers to the surface of clays is well documented (Cary et al., 1987). Soil particles could reduce the toxicity of chitosan and cationic starch to the aquatic organism by adsorbing much of the flocculants onto soil surfaces. The flocculant modified/adsorbed soil particles are not only less toxic but also more effective in flocculating algae cells especially at high particle concentration where collision between the modified soil particles and the algae cells can be effectively increased (Li and Pan, 2013).

Suspended particles (SP) are ubiquitous in natural waters. The mean SP concentration can range from 2 to $200 \mathrm{mg} / \mathrm{L}$ (Bolto and Gregory, 2007) to as high as $65 \mathrm{~g} / \mathrm{L}$ in the Yellow River (Pan et al., 2013). The application dosage of soil is generally comparable to the SP concentration in many nature waters (Li and Pan, 2013; Zou et al., 2006). SP (>500 mg/L) itself showed no toxic effect to the four aquatic species (Table 2). The concentrations of metal leached from the soil at $\mathrm{pH} 7.85$ and 4.93 are far below the $\mathrm{EC}_{50}$ of these metals to D. manga (Table 1). It can be confirmed that chitosan and cationic starch is the main toxic components in the modified soil. Since the toxicity of these modifiers can be reduced after combining them with soil/clay particles, flocculants modified soil or clay provide an approach to improve the ecological safety of the cationic polymers 


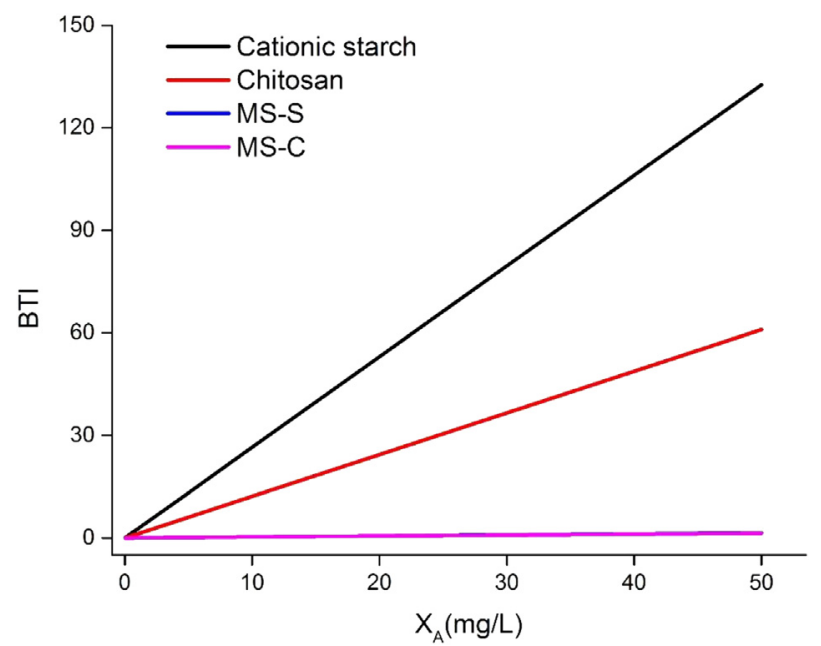

Fig. 4. The functional relation between $B T I$ and dosage $\left(X_{A}\right)$ of the four flocculants.

for HABs control.

\subsection{Biotic toxicity index}

As a toxicity assessment and screening tool for the lake geoengineering materials, BTI could be used to assess the toxicity of flocculants on aquatic organisms in three scenarios. In this work, we calculated the BTI of chitosan and cationic starch in scenario 1 since both chitosan and cationic starch are biodegradable in the aquatic ecosystem. There is a single linear regress relationship between BTI and the dosage of flocculants $\left(X_{A}\right)$ when $N=1$. The contents of modifier in MS were often below $10 \%$ in the published literature and the MS usually shows higher flocculation efficiency (Table 3). Some clays can flocculate algae cells without being modified by flocculants (Lewis et al., 2003; Pan et al., 2006). The flocculation ability of soil/clay was improved by adding chitosan or cationic starch, however, the toxicity of modifier was correspondingly reduced.

In lake geo-engineering, mineral-based byproducts and inorganic flocculant have been used widely. The application of nondegradable inorganic salts may increase the metal (e.g. aluminum, iron, lanthanum) concentration in natural waters. The metals may be ingested and accumulated in biological bodies or transport to a higher trophic level through aquatic food chain (Cui et al., 2011) and produce adverse impacts such as deformities and death on aquatic organisms (Bird et al., 2008). We can use formula (2) to calculate the BTI of non-biodegradable flocculant in scenario 2 if there is not food chain relationship among the test organisms. In this situation, the bioconcentration factor (BCF) was introduced into formula (2). So the BTI has exponential relationship to the practical dosage $X_{A}$, and the BTI of non-biodegradable flocculant grew more faster than biodegradable flocculants with the increased of $X_{A}$.

In practical applications, lake managers are more concerned about the impacts of flocculants on actual aquatic ecosystem than standardized laboratory toxicity tests (the latter are more replicable which is important for experiments). If the organisms in the bioassay battery are from the same aquatic ecosystem, they can form an actual food chain relationship. In this scenario, the trophic level and biomagnification action were considered and biomagnification factor (BMF) was introduced. Due to the biomagnification, the higher trophic level may suffer from more damages than the lower one. Under this scenario, the BTI also has exponential relationship to the practical dosage $X_{A}$. It is possible to obtain the toxicity effects of the non-biodegradable flocculants to the aquatic food chain. With toxicity data of metal salts and with well established methods for obtaining the battery in the same system, scenario 2 and 3 can be measured in separate studies. Nevertheless, the BTI provided here could provide useful information for the lake manager to screen and rank the toxicity of flocculants for the lake geo-engineering.

Although the BTI can be used to reveal the biotic toxicity of flocculants it still has several limitations which must be further studied. Firstly, toxicity values are based on short-term laboratory experiments with acute $E C_{50}$ endpoints; the BTI does not reflect long-term/chronic exposure or incorporate sublethal endpoints. Secondly, the BTI does not account for many environmental factors, which can affect the toxicity and bioavailability of the flocculants. More comprehensive studies on ecotoxicological effect of geoengineering materials are needed before they can be widely applied in natural waters at large scale.

\subsection{Implication for lake geo-engineering}

Although natural flocculants have the potential to be more biodegradable and environmental friendly than non-degradable chemical salts (Bolto and Gregory, 2007), it does not necessarily imply that they are ecologically safe for the aquatic system especially when they are modified by chemical reactions. Before these materials can be used in field at large scale, their ecological safety and ecotoxicology should be comprehensively studied. Our results demonstrated that using chitosan or cationic starch alone may cause some toxic effects to the aquatic biota (Table 2). The aquatic organisms may suffer from movement inhibition or pathological changes of tissues at low concentration of chitosan or cationic starch (Figs. 2 and 3). By modifying with the soil/clay particles, the acute toxicity of chitosan and cationic starch can be largely decreased while the flocculation efficiency is substantially enhanced (Li and Pan, 2013; Zou et al., 2006). A preliminary toxicity test is necessary to screen the toxicity risk of flocculants before practical application. The BTI method proposed here is a comparable and quantitative method which can reflect the toxicity of flocculant to the aquatic organisms.

Table 3

BTI for MS-C, MS-S according to the practical dosage $\left(X_{A}\right)$ of flocculants in the published literature.

\begin{tabular}{|c|c|c|c|c|c|c|c|}
\hline \multicolumn{2}{|c|}{$\begin{array}{l}\text { Modified soil/clay } \\
\text { flocculant }\end{array}$} & \multirow[t]{2}{*}{ BTI } & \multirow[t]{2}{*}{ Chitosan in MS $(\mathrm{mg} / \mathrm{L})$} & \multirow[t]{2}{*}{ BTI } & \multirow[t]{2}{*}{ Cationic starch in MS (mg/L) } & \multirow[t]{2}{*}{ BTI } & \multirow[t]{2}{*}{ Reference } \\
\hline Type & $\left(X_{A}\right) \mathrm{mg} / \mathrm{L}$ & & & & & & \\
\hline \multirow[t]{4}{*}{ MS-C } & 11 & 0.3 & 1 & 1.2 & & & Zou et al., 2006 \\
\hline & 25 & 0.7 & 2.5 & 3.1 & & & Pan et al., 2006 \\
\hline & 77 & $<0.6$ & 2 & 2.4 & & & Pan et al., 2012 \\
\hline & 102 & $<0.6$ & 2 & 2.4 & & & Li and Pan, 2013 \\
\hline MS-S & 110 & 3.3 & & & 10 & 26.5 & Shi et al., 2016 \\
\hline
\end{tabular}




\section{Conclusion}

Biotic toxicity index (BTI) was used to assess the toxicity potential of four representative geo-engineering materials including chitosan, cationic starch, chitosan modified soil, cationic starch modified soil to the aquatic organisms. The fact that $\mathrm{EC}_{50}$ values of chitosan and cationic starch are much lower than that of chitosan or cationic starch modified soil/clay materials indicates that direct use of chitosan or cationic starch alone as flocculants has a much higher toxic risk than the modified soil/clay materials. When MS-C and/or MS-S are used at the optimized dosage of $11-110 \mathrm{mg} / \mathrm{L}$, it may not cause substantial adverse effects to the four representative organisms in aquatic ecosystem. The main acute toxic effect of flocculants on the fish was pathological changes of gill tissues caused by the affinity of flocs to the biological surface. The results of BTI indicated that the potential impact of flocculants on the aquatic organisms was in order: cationic starch $>$ chitosan $>$ MS-C $>$ MS-S. The BTI can be used to describe the toxic effects of biodegradable or nonbiodegradable flocculants on the aquatic organisms or food chain.

\section{Acknowledgments}

The research was supported by the Strategic Priority Research Program of CAS (XDA09030203), the Science Promotion Program of RCEES, CAS (YSW2013B05), and National Natural Science Foundation of China (41401551).

\section{Appendix A. Supplementary information}

Supplementary information related to this article can be found at http://dx.doi.org/10.1016/j.watres.2015.08.033.

\section{References}

Akyuz, D.E., Luo, L., Hamilton, D.P., 2014. Temporal and spatial trends in water quality of Lake Taihu, China: analysis from a north to mid-lake transect, 1991-2011. Environ. Monit. Assess. 186 (6), 3891-3904.

Anthony, R., Sims, R., 2013. Cationic starch for microalgae and total phosphorus removal from wastewater. J. Appl. Polym. Sci. 130 (4), 2572-2578.

Antunes, S.C., de Figueiredo, D.R., Marques, S.M., Castro, B.B., Pereira, R., Gonçalves, F., 2007. Evaluation of water column and sediment toxicity from an abandoned uranium mine using a battery of bioassays. Sci. Total Environ. 374 (2-3), 252-259.

Biesinge, K.E., Christen, G.M., 1972. Effects of various metals on survival, growth, reproduction, and metabolism of daphnia-magna. J. Fish. Res. Board Can. 29 (12), 1691-1700.

Bird, D.J., Rotchell, J.M., Hesp, S.A., Newton, L.C., Hall, N.G., Potter, I.C., 2008. To what extent are hepatic concentrations of heavy metals in Anguilla anguilla at a site in a contaminated estuary related to body size and age and reflected in the metallothionein concentrations? Environ. Pollut. 151 (3), 641-651.

Bolto, B., Gregory, J., 2007. Organic polyelectrolytes in water treatment. Water Res. 41 (11), 2301-2324.

Bullock, G., Blazer, V., Tsukuda, S., Summerfelt, S., 2000. Toxicity of acidified chitosan for cultured rainbow trout (Oncorhynchus mykiss). Aquaculture 185 (3-4), 273-280.

Burson, A., Matthijs, H.C.P., de Bruijne, W., Talens, R., Hoogenboom, R., Gerssen, A., Visser, P.M., Stomp, M., Steur, K., van Scheppingen, Y., Huisman, J., 2014 Termination of a toxic Alexandrium bloom with hydrogen peroxide. Harmful Algae 31 (0), 125-135.

Cary, G.A., McMahon, J.A., Kuc, W.J., 1987. The effect of suspended-solids and naturally-occurring dissolved organics in reducing the acute toxicities of cationic polyelectrolytes to aquatic organisms. Environ. Toxicol. Chem. 6 (6), $469-474$.

Clearwater, S.J., Hickey, C.W., Thompson, K.J., 2014. The effect of chronic exposure to phosphorus-inactivation agents on freshwater biota. Hydrobiologia 728 (1), $51-65$.

Costa, R., Pereira, J.L., Gomes, J., Goncalves, F., Hunkeler, D., Rasteiro, M.G., 2014. The effects of acrylamide polyelectrolytes on aquatic organisms: relating toxicity to chain architecture. Chemosphere 112, 177-184.

Costan, G., Bermingham, N., Blaise, C., Ferard, J.F., 1993. Potential ecotoxic effects probe (peep) - a novel index to assess and compare the toxic potential of industrial effluents. Environ. Toxicol. Water Qual. 8 (2), 115-140.

Cui, B., Zhang, Q., Zhang, K., Liu, X., Zhang, H., 2011. Analyzing trophic transfer of heavy metals for food webs in the newly-formed wetlands of the Yellow River
Delta, China. Environ. Pollut. 159 (5), 1297-1306.

de Rosemond, S.J.C., Liber, K., 2004. Wastewater treatment polymers identified as the toxic component of a diamond mine effluent. Environ. Toxicol. Chem. 23 (9), 2234-2242.

Eyckmans, M., Benoot, D., Van Raemdonck, G.A.A., Zegels, G., Van Ostade, X.W.M. Witters, E., Blust, R., De Boeck, G., 2012. Comparative proteomics of copper exposure and toxicity in rainbow trout, common carp and gibel carp. Comp. Biochem. Physiol. Part D Genom. Proteom. 7 (2), 220-232.

Fan, J., Ho, L., Hobson, P., Brookes, J., 2013. Evaluating the effectiveness of copper sulphate, chlorine, potassium permanganate, hydrogen peroxide and ozone on cyanobacterial cell integrity. Water Res. 47 (14), 5153-5164.

Gibbs, M., Oezkundakci, D., 2011. Effects of a modified zeolite on P and N processes and fluxes across the lake sediment-water interface using core incubations. Hydrobiologia 661 (1), 21-35.

Goodrich, M.S., Dulak, L.H., Friedman, M.A., Lech, J.J., 1991. Acute and long-term toxicity of water-soluble cationic polymers to rainbow-trout (oncorhynchusmykiss) and the modification of toxicity by humic-acid. Environ. Toxicol. Chem. 10 (4), 509-515.

Hansel, P.A., Guy Riefler, R., Stuart, B.J., 2014. Efficient flocculation of microalgae for biomass production using cationic starch. Algal Res. 5 (0), 133-139.

Hartwell, S.I., 1997. Demonstration of a toxicological risk ranking method to correlate measures of ambient toxicity and fish community diversity. Environ. Toxicol. Chem. 16 (2), 361-371.

Hoekstra, P.F., O'Hara, T.M., Fisk, A.T., Borga, K., Solomon, K.R., Muir, D.C.G., 2003. Trophic transfer of persistent organochlorine contaminants (OCs) within an Arctic marine food web from the southern Beauforte Chukchi Seas. Environ. Pollut. 124 (3), 509-522.

Kim, J.-D., Kim, B., Lee, C.-G., 2007. Alga-lytic activity of Pseudomonas fluorescens against the red tide causing marine alga Heterosigma akashiwo (Raphidophyceae). Biol. Control 41 (3), 296-303.

Lürling, M., Tolman, Y., 2010. Effects of lanthanum and lanthanum-modified clay on growth, survival and reproduction of Daphnia magna. Water Res. 44 (1), 309-319.

Lee, C.S., Robinson, J., Chong, M.F., 2014. A review on application of flocculants in wastewater treatment. Process Saf. Environ. Prot. 92 (6), 489-508.

Letelier-Gordo, C.O., Holdt, S.L., De Francisci, D., Karakashev, D.B., Angelidaki, I. 2014. Effective harvesting of the microalgae Chlorella protothecoides via bioflocculation with cationic starch. Bioresour. Technol. 167 (0), 214-218.

Lewis, M.A., Dantin, D.D., Walker, C.C., Kurtz, J.C., Greene, R.M., 2003. Toxicity of clay flocculation of the toxic dinoflagellate, Karenia brevis, to estuarine invertebrates and fish. Harmful Algae 2 (4), 235-246.

Li, H., Pan, G., 2015. Simultaneous removal of harmful algal blooms and microcystins using microorganism and chitosan-modified local soil. Environ. Sci. Technol. 49 (10), 6249-6256.

Li, L., Pan, G., 2013. A universal method for flocculating harmful algal blooms in marine and fresh waters using modified sand. Environ. Sci. Technol. 47 (9), 4555-4562.

Li, P., Song, Y., Yu, S., 2014. Removal of Microcystis aeruginosa using hydrodynamic cavitation: performance and mechanisms. Water Res. 62 (0), 241-248.

Liber, K., Weber, L., Levesque, C., 2005. Sublethal toxicity of two wastewater treatment polymers to lake trout fry (Salvelinus namaycush). Chemosphere 61 (8), 1123-1133.

Mackay, E.B., Maberly, S.C., Pan, G., Reitzel, K., Bruere, A., Nicholas Corker, G., Douglas, S.E., Hamilton, D., Hatton-Ellis, T., Huser, B., Li, W., Meis, S., Moss, B. Lürling, M., Phillips, G., Yasseri, S., Spears, B.M., 2014. Geoengineering in lakes: welcome attraction or fatal distraction? Inland Waters 4.

McGeer, J.C., Brix, K.V., Skeaff, J.M., Deforest, D.K., Brigham, S.I., Adams, W.J. Green, A., 2003. Inverse relationship between bioconcentration factor and exposure concentration for metals: implications for hazard assessment of metals in the aquatic environment. Environ. Toxicol. Chem. 22 (5), 1017-1037.

Meis, S., Spears, B.M., Maberly, S.C., Perkins, R.G., 2013. Assessing the mode of action of Phoslock ( $\mathrm{R}$ ) in the control of phosphorus release from the bed sediments in a shallow lake (Loch Flemington, UK). Water Res. 47 (13), 4460-4473.

Nan, C., Zhang, H., Lin, S., Zhao, G., Liu, X., 2008. Allelopathic effects of Ulva lactuca on selected species of harmful bloom-forming microalgae in laboratory cultures. Aquat. Bot. 89 (1), 9-15.

Nowell, L.H., Norman, J.E., Moran, P.W., Martin, J.D., Stone, W.W., 2014. Pesticide Toxicity Index-A tool for assessing potential toxicity of pesticide mixtures to freshwater aquatic organisms. Sci. Total Environ. 476-477 (0), 144-157.

Paerl, H.W., Huisman, J., 2008. Climate. Blooms like it hot. Science 320 (5872), 57-58.

Pan, G., Zou, H., Chen, H., Yuan, X., 2006. Removal of harmful cyanobacterial blooms in Taihu Lake using local soils. III. Factors affecting the removal efficiency and an in situ field experiment using chitosan-modified local soils. Environ. Pollut. 141 (2), 206-212.

Pan, G., Dai, L., Li, L., He, L., Li, H., Bi, L., Gulati, R.D., 2012. Reducing the recruitment of sedimented algae and nutrient release into the overlying water using modified soil/sand flocculation-capping in eutrophic lakes. Environ. Sci. Technol. 46 (9), 5077-5084.

Pan, G., Krom, M.D., Zhang, M., Zhang, X., Wang, L., Dai, L., Sheng, Y. Mortimer, R.J.G., 2013. Impact of suspended inorganic particles on phosphorus cycling in the Yellow River (China). Environ. Sci. Technol. 47 (17), 9685-9692.

Rinaudo, M., 2006. Chitin and chitosan: properties and applications. Prog. Polym. Sci. 31 (7), 603-632.

Rizzo, L., Di Gennaro, A., Gallo, M., Belgiorno, V., 2008. Coagulation/chlorination of 
surface water: a comparison between chitosan and metal salts. Sep. Purif. Technol. 62 (1), 79-85.

Rowland, C.D., Burton, G.A., Morrison, S.M., 2000. Implication of polymer toxicity in a municipal wastewater effluent. Environ. Toxicol. Chem. 19 (8), 2136-2139.

Shi, W.Q., Tan, W.Q., Wang, L.J., Pan, G., 2016. Removal of Microcystis aeruginosa using cationic starch modified soils. Water Res. 97, 19-25. http://dx.doi.org/ 10.1016/j.watres.2015.06.029.

Spears, B.M., Maberly, S.C., Pan, G., Mackay, E., Bruere, A., Corker, N., Douglas, G., Egemose, S., Hamilton, D., Hatton-Ellis, T., Huser, B., Li, W., Meis, S., Moss, B. Lurling, M., Phillips, G., Yasseri, S., Reitzel, K., 2014. Geo-engineering in lakes: crisis of confidence? Environ. Sci. Technol. 48 (17), 9977-9979.

Tigini, V., Giansanti, P., Mangiavillano, A., Pannocchia, A., Varese, G.C., 2011. Evaluation of toxicity, genotoxicity and environmental risk of simulated textile and tannery wastewaters with a battery of biotests. Ecotoxicol. Environ. Saf. 74 (4), $866-873$.

USEPA, 1992. Toxicity Characteristic Leaching Procedure.

Wang, L., Liang, W., Yu, J., Liang, Z., Ruan, L., Zhang, Y., 2013. Flocculation of
Microcystis aeruginosa using modified larch tannin. Environ. Sci. Technol. 47 (11), 5771-5777.

Ward, R.J.S., McCrohan, C.R., White, K.N., 2006. Influence of aqueous aluminium on the immune system of the freshwater crayfish Pacifasticus leniusculus. Aquat. Toxicol. 77 (2), 222-228.

Wei, D., Lin, Z., Kameya, T., Urano, K., Du, Y., 2008. Application of biological safety index in two Japanese watersheds using a bioassay battery. Chemosphere 72 (9), 1303-1308.

Wei, D., Tan, Z., Du, Y., 2011. A biological safety evaluation on reclaimed water reused as scenic water using a bioassay battery. J. Environ. Sci. 23 (10), $1611-1618$.

Xu, Y., Purton, S., Baganz, F., 2013. Chitosan flocculation to aid the harvesting of the microalga Chlorella sorokiniana. Bioresour. Technol. 129 (0), 296-301.

Zou, H., Pan, G., Chen, H., Yuan, X., 2006. Removal of cyanobacterial blooms in Taihu Lake using local soils. II. Effective removal of Microcystis aeruginosa using local soils and sediments modified by chitosan. Environ. Pollut. 141 (2), $201-205$. 